\title{
The Hypothalamic-Pituitary-Adrenal Axis in Critical Illness: Response to Dexamethasone and Corticotropin- Releasing Hormone
}

\author{
MARTIN REINCKE, BRUNO ALLOLIO, GUIDO WÜRTH, AND \\ WERNER WINKELMANN \\ Department of Medicine, University of Wurzburg (M.R., B.A.), and the Department of Medicine II, \\ University of Koln, Krankenhaus Merheim, Germany
}

\begin{abstract}
Plasma ACTH and cortisol concentrations are frequently elevated in patients in intensive care units (ICU). To examine the functional integrity of the hypothalamic-pituitary-adrenal axis during critical illness, we evaluated prospectively 53 ICU patients in a general medical ICU. Thirty-one patients and 7 normal controls underwent an overnight dexamethasone suppression test ( $3 \mathrm{mg}$ dexamethasone, orally, at $2300 \mathrm{~h}$ ). Plasma ACTH and serum cortisol were measured at $0900 \mathrm{~h}$. In a separate experiment, 22 patients and 7 control subjects underwent a CRH stimulation test [100 $\mu \mathrm{g}$ human (h) $\mathrm{CRH}$, iv]. ACTH and cortisol concentrations were determined from -15 to $120 \mathrm{~min}$. Compared to normal controls, plasma ACTH and serum cortisol concentrations were not fully suppressible by dexamethasone [mean \pm SEM: plasma ACTH, $21 \pm 4$ vs. $3 \pm 0.5 \mathrm{pg} / \mathrm{mL}$ (4.7 \pm 0.9 vs. $0.7 \pm 0.1 \mathrm{pmol} /$ L); serum cortisol, $13.9 \pm 1.9$ us. $1.5 \pm 0.3 \mu \mathrm{g} / \mathrm{dL}(390 \pm 50$ vs. $40 \pm 10$ $\mathrm{nmol} / \mathrm{L}) ; P=0.0001$ ], demonstrating an altered glucocorticoid feedback in the ICU patients. Patients undergoing hCRH stimulation had clearly
\end{abstract}

elevated mean baseline plasma ACTH and serum cortisol concentrations $[\mathrm{ACTH}, 78 \pm 20 \mathrm{pg} / \mathrm{mL}$ vs. $15 \pm 3$ in controls $(17.2 \pm 4.4$ vs. 3.4 $\pm 0.7 \mathrm{pmol} / \mathrm{L} ; P=0.007) ;$ cortisol, $36.8 \pm 3.4 \mu \mathrm{g} / \mathrm{dL}$ vs. $9.6 \pm 1.2(1020$ \pm 80 vs. $260 \pm 30 \mathrm{nmol} / \mathrm{L} ; P=0.0001)$ ]. Despite elevated baseline glucocorticoid concentrations, stimulation with hCRH resulted in significantly higher peak plasma ACTH concentrations $15 \mathrm{~min}$ after hCRH than in controls $[134 \pm 31$ vs. $48 \pm 9 \mathrm{pg} / \mathrm{mL}(29.5 \pm 6.8$ vs. 10.6 $\pm 2.0 \mathrm{pmol} / \mathrm{L}) ; P<0.05$ ]. Serum cortisol concentrations in ICU patients were significantly elevated throughout the test period $(P=0.0001)$ and rose to a peak of $43.9 \pm 3.5 \mu \mathrm{g} / \mathrm{dL}$ compared to $18.2 \pm 2.0 \mu \mathrm{g} / \mathrm{dL}$ in controls $(1210 \pm 70$ vs. $500 \pm 60 \mathrm{nmol} / \mathrm{L})$. We conclude that ICU patients have a markedly altered responsiveness of their pituitary corticotroph to suppression with dexamethasone and stimulation with $\mathrm{hCRH}$. These findings may be explained by altered pituitary glucocorticoid feedback and/or hypersecretion of peptides with CRH-like activity (vasopressin and cytokines) during critical illness. ( $J$ Clin Endocrinol Metab 77: 151-156, 1993)
$\mathrm{P}$ REVIOUS studies demonstrated that critical illness, such as in patients in intensive care units (ICU), is associated with changes in the hypothalamic-pituitary-adrenal (HPA) (1-10), hypothalamic-pituitary-thyroid (11-13), and gonadal (14-18) axes; the renin-angiotensin system (19-22); and the sympathoadreno-medullary system $(6,23)$. The response of the HPA axis has been shown to be essential for adaptation and maintenance of homeostasis during critical illness (24). One of the main functions of glucocorticoids seems to be modulation and coordination of the stress response by interacting with other elements of the stress defense (i.e. hormones, cytokines, lipid mediators of inflammation, and bioactive peptides) (24).

Patients in ICUs have elevated baseline cortisol concentrations, which are positively correlated with the degree of illness as well as with the mortality rate $(5,7)$. Furthermore, patients in ICUs have, compared to controls, higher cortisol levels after stimulation with ACTH-(1-24), reflecting adaptation of the adrenal cortex during major stress $(5,10)$. The baseline adrenal steroid secretion shows a shift away from adrenal androgen and mineralocorticoid secretion toward glucocorticoid secretion $(1,15,17,19,20)$.

Received October 20, 1992

Address all correspondence and requests for reprints to: Dr. Martin Reincke, Department of Medicine, University of Wurzburg, Josef-Schneider-Strasse. 2, 8700 Wurzburg, Germany.
The regulation of the HPA axis during critical illness has not been studied in detail. We, therefore, studied the response of the HPA axis to suppression with dexamethasone and stimulation with human (h) $\mathrm{CRH}$ in 53 ICU patients and 14 normal controls.

\section{Subjects and Methods}

\section{Patients}

The study was performed during a 6-month period in the medical ICU of the Medical Department II, Krankenhaus Merheim, University of Koln. Krankenhaus Merheim is an 800 -bed tertiary care hospital. The ICU is a 9-bed unit, treating approximately 400 patients/yr, mainly patients with cardiac or renal disease. The frequency of respirator treatment is $50 \%$. The protocol was approved by the Institutional Review Board, University of Koln, and all patients or their first degree relatives and all normal subjects gave written informed consent.

Patients were enrolled in this study regardless of the medical condition responsible for transfer to the ICU. They were studied as soon as informed consent could be obtained and as soon as their medical condition had been stabilized. Routine medical treatment was given as required. Patients with known diseases of the HPA axis, hypoxic brain damage, glucocorticoid treatment, gastrointestinal bleeding, fever higher than $38.5 \mathrm{C}$, or emergency procedures, such as surgery, within $48 \mathrm{~h}$ were excluded from the study.

In all 53 patients studied, age, sex, main diagnosis, and outcome (inhospital mortality) were determined. The severity of illness was assessed on the day the tests were performed using the Therapeutical Intervention System Score (TISS-24) (25), which estimates the degree of illness by 
measuring the intensity of treatment given to a particular patient. Blood was drawn from either peripheral indwelling catheters or internal jugular venous catheters.

\section{Dexamethasone suppression test}

Thirty-one patients and seven normal subjects underwent an overnight dexamethasone suppression test. Clinical data for the study population are shown in Table 1 . At $0900 \mathrm{~h}$ on day 1 , blood was drawn for determination of plasma ACTH and serum cortisol. At $2300 \mathrm{~h}$, all subjects received $3 \mathrm{mg}$ dexamethasone, orally (nonintubated patients) or via a gastric tube (patients receiving respirator therapy), followed by determination of plasma ACTH and serum cortisol the following day at $0900 \mathrm{~h}$.

\section{hCRH stimulation test}

In a separate experiment, 22 patients and 7 normal subjects underwent a hCRH test at $0900 \mathrm{~h}$ in the morning. The characteristics of the

TABLE 1. Clinical profile of patients who had a dexamethasone suppression test

\begin{tabular}{lcc}
\hline & Controls & ICU patients \\
\hline $\mathrm{n}$ & 7 & 31 \\
Sex & $5 \mathrm{~F} / 2 \mathrm{M}$ & $15 \mathrm{~F} / 16 \mathrm{M}$ \\
Age $(\mathrm{yr})$ & $58 \pm 14$ & $67 \pm 11$
\end{tabular}

Day of test after admission to ICU

Mean TISS

Respiratory therapy (\%)

Mortality (\%)

Main diagnosis

Myocardial infarction

Chronic heart failure

Cardiogenic shock

Acute renal failure

Chronic renal failure

Liver failure

ARDS

$6.1 \pm 3.9(2-16)^{a}$

39

41

F, Female; M, male; TISS, Therapeutical Intervention System Score; ARDS, adult respiratory distress syndrome.

The mean \pm SD are shown.

${ }^{a}$ Range is in parentheses.

TABLE 2. Clinical profile of patients who had a hCRH stimulation test

\begin{tabular}{lcc}
\hline & Controls & ICU patients \\
\hline $\mathrm{n}$ & 7 & 22 \\
Sex & $5 \mathrm{~F} / 2 \mathrm{M}$ & $6 \mathrm{~F} / 16 \mathrm{M}$ \\
Age $(\mathrm{yr})$ & $61 \pm 11$ & $64 \pm 12$
\end{tabular}

Day of test after admission to ICU

Mean TISS

Respiratory therapy (\%)

Mortality (\%)

Main diagnosis

Myocardial infarction

Chronic heart failure

Pulmonary edema

Cardiogenic shock

Acute renal failure

ARDS

Liver failure

Sepsis/septic shock

$$
\begin{gathered}
6.0 \pm 6.15(2-25)^{a} \\
39 \pm 10(15-54) \\
82 \\
68 \\
2 \\
3 \\
2 \\
4 \\
2 \\
2 \\
4
\end{gathered}
$$

F, Female; M, male; TISS, Therapeutical Intervention System Score; ARDS, adult respiratory distress syndrome. Shown are the mean $\pm \mathrm{SD}$.

${ }^{a}$ Range is in parentheses. subjects are shown in Table 2. After 2 baseline blood samples for determination of plasma ACTH and serum cortisol (-15 and $0 \mathrm{~min}$ ), hCRH (Corticobiss, Bissendorf Peptide, Hannover, Germany) was injected as a bolus dose of $100 \mu \mathrm{g}$, iv. Blood was drawn at $15,30,45,60$ 90 , and $120 \mathrm{~min}$.

\section{Hormone assays}

Plasma ACTH was determined after extraction with Quso $\mathrm{G}_{32}$ (Philadelphia Quartz Co.) (26). The lower limit of detection was $3 \mathrm{pg} / \mathrm{mL}$. Serum cortisol was measured by a commercial enzyme-linked immunosorbent assay (Serozym, Serono, Freiburg, Germany). The inter- and intraassay coefficients of variation were below $9 \%$ and $6 \%$ for both assays, respectively. All samples from a patient were measured in the same assay.

\section{Data analysis}

The total and net integrated ACTH and cortisol responses to hCRH were calculated by the trapezoid method and expressed as the area under the concentration-time curve (AUC) from 0-120 min. All values are expressed as the mean \pm SEM, if not otherwise stated. Statistical significance of the differences was assessed using the Mann-Whitney $U$ test for unpaired data. Correlations were examined with linear regression analysis and expressed as the Pearson's correlation coefficient. $P \leq 0.05$ was considered statistically significant.

\section{Results}

\section{Dexamethasone suppression test}

Compared to normal subjects, baseline plasma ACTH concentrations at $0900 \mathrm{~h}$ were slightly, but not significantly, higher in ICU patients, whereas baseline cortisol concentrations were clearly elevated (Fig. 1). After dexamethasone
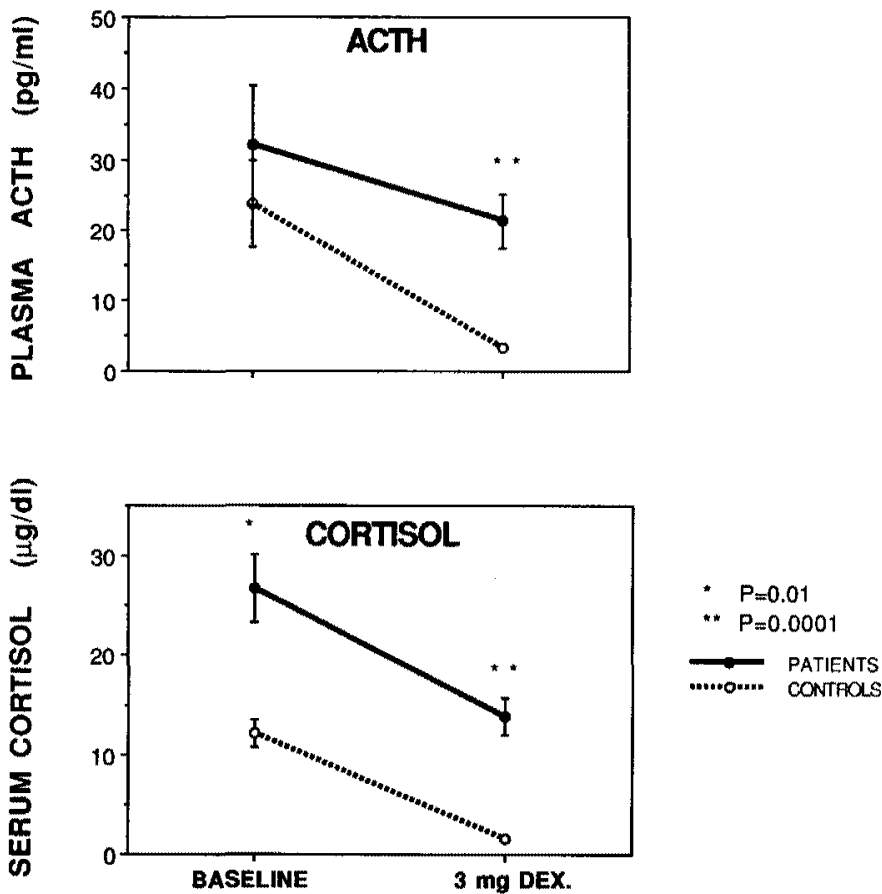

Fig. 1. Mean responses of plasma ACTH and serum cortisol to suppression with dexamethasone in 7 normal controls and 31 ICU patients. To convert ACTH concentrations to picomoles per L, multiply by 0.2202 ; to convert cortisol concentrations to nanomoles per $\mathrm{L}$, multiply by 27.6 . 
administration, plasma $\mathrm{ACTH}$ as well as cortisol concentrations were suppressed in normal subjects. In contrast, ICU patients showed significantly elevated mean ACTH $(P=$ $0.0001)$ and cortisol concentrations $(P=0.0001)$, demonstrating an altered negative feedback regulation of glucocorticoids during critical illness.

ACTH and cortisol concentrations in ICU patients were significantly correlated with the in-hospital mortality rate (Table 3). Patients who later died during the hospital stay had higher postdexamethasone ACTH concentrations ( $P=$ $0.02)$ and cortisol concentrations $(P=0.04)$ than patients who were discharged from the hospital.

\section{hCRH stimulation test}

Baseline plasma ACTH concentrations showed a great variability in ICU patients, but were significantly higher than those in the controls (Fig. 2; $P=0.007$ ). In addition, baseline cortisol concentrations were significantly elevated $(P=$ 0.0001 ). The individual ACTH response to $h C R H$ in ICU patients was characterized by an ACTH increase ranging from $7-450 \%$ of the baseline value and was not dependent on the baseline cortisol concentrations ( $\mathrm{r}=0.05 ; p=0.8)$. Mean ACTH concentrations rose to a peak of $134 \pm 31 \mathrm{pg} /$ $\mathrm{mL}(29.5 \pm 6.9 \mathrm{pmol} / \mathrm{L}) 15 \mathrm{~min}$ after the injection of hCRH compared with $48 \pm 9 \mathrm{pg} / \mathrm{mL}(10.6 \pm 2.0 \mathrm{pmol} / \mathrm{L})$ in control subjects ( $P=0.046$; Fig. 2$)$. The total AUC and the maximum $\mathrm{ACTH}$ concentrations (Fig. 3), but not the net AUC, were also significantly higher than those in controls.

Mean cortisol concentrations in ICU patients were significantly elevated throughout the test period $(P<0.0001)$, and the total AUC for cortisol was clearly higher than that in the controls $(P=0.0001)$. The cortisol increase in ICU patients $(P=0.8)$ as well as the net AUC $(P=0.4)$ were similar in ICU patients and controls.

Baseline ACTH concentrations were significantly higher in patients who later died during the hospital stay than those in patients who survived and were discharged from the hospital $[95 \pm 28$ vs. $42 \pm 16 \mathrm{pg} / \mathrm{mL}(20.9 \pm 6.1$ vs. $9.2 \pm$ $3.5 \mathrm{pmol} / \mathrm{L}) ; P=0.04$ ]. In addition, the total AUC of nonsurvivors was significantly higher than that in control subjects $(P=0.04$; Table 3$)$, whereas survivors did not have significantly higher total AUC than controls. Baseline serum cortisol concentrations and the total time-integrated cortisol secretion did not differ between patients who later died and patients who survived.

\section{Discussion}

The response of the HPA axis has been shown to be an integral part of the adaptation to emotional and physical stress. Critical illness, such as in ICU patients, is one of the most powerful activators of the HPA axis. ACTH and cortisol concentrations in sepsis (8), after extensive burns (15) or brain trauma (9), or in shock are elevated and may reach extraordinarily high levels depending on the degree of illness. Whereas it is well established that ICU patients have biochemical evidence of hypercortisolism, little is known of the functional integrity of the HPA axis during critical illness. The data from our dynamic evaluation show that the response of the HPA axis to suppression by dexamethasone and stimulation by hCRH is profoundly altered in ICU patients. Treatment of ICU patients with dexamethasone at a dose that easily suppresses ACTH and cortisol secretion in normal subjects was minimally effective in our patients. In addition, stimulation with hCRH resulted in an augmented ACTH response in spite of very high baseline cortisol concentrations, which probably would have been sufficient to blunt or abolish the hCRH-induced ACTH surge in normal subjects. Taken together, the observed abnormalities in the HPA axis of ICU patients are unique and have not been reported in any of the well characterized biochemically hypercortisolemic states, such as major depression (27), pregnancy (28), and renal insufficiency (29). The comparison to the findings in major depression is particularly noteworthy, since chronic emotional stress associated with depression may be seen as a counterpart to the chronic physical stress of ICU patients. Similar to ICU patients, patients with depression are also hypercortisolemic and show a blunted cortisol response to suppression with dexamethasone (27). However, the response to exogenous stimulation with $\mathrm{CRH}$ in depressed patients is characterized by a blunted ACTH response, presumably because of the negative feedback of elevated endogenous glucocorticoids on ACTH release. In contrast, in ICU patients, the negative feedback of endogenous glucocorticoids on pituitary ACTH secretion is clearly altered, and stimulation with hCRH results in high plasma ACTH concentrations in spite of elevated baseline cortisol

TABLE 3. Influence of subsequent mortality on ACTH and cortisol responses to dexamethasone and CRH

\begin{tabular}{|c|c|c|c|c|c|c|}
\hline & \multicolumn{4}{|c|}{ Dexamethasone suppression test } & \multicolumn{2}{|c|}{ hCRH stimulation test } \\
\hline & $\begin{array}{c}\text { Basal ACTH }[\mathrm{pg} / \mathrm{mL} \\
\text { (pmol/L)] }\end{array}$ & $\begin{array}{l}\text { ACTH after } 3 \mathrm{mg} \text { dex } \\
{[\mathrm{pg} / \mathrm{mL}(\mathrm{pmol} / \mathrm{L})]}\end{array}$ & $\begin{array}{l}\text { Basal cortisol }[\mu \mathrm{g} / \mathrm{dL} \\
(\mathrm{nmol} / \mathrm{L})]\end{array}$ & $\begin{array}{l}\text { Cortisol after } 3 \mathrm{mg} \text { dex } \\
{[\mu \mathrm{g} / \mathrm{dL}(\mathrm{nmol} / \mathrm{L})]}\end{array}$ & $\begin{array}{c}\text { Total AUC } \\
\text { ACTH }(\mathrm{pg} / \mathrm{mL} \\
\mathrm{min})\end{array}$ & $\begin{array}{l}\text { Total AUC } \\
\text { cortisol }(\mu \mathrm{g} / \\
\mathrm{dL} \cdot \mathrm{min})\end{array}$ \\
\hline Controls & $24 \pm 6 \quad(5.3 \pm 1.2)$ & $3 \pm 0.5(0.7 \pm 0.1)$ & $12.1 \pm 1.2(330 \pm 30)$ & $1.5 \pm 0.3(40 \pm 10)$ & $4,390 \pm 570$ & $1,881 \pm 213$ \\
\hline Patients & & & & & & \\
\hline Survivors & $26 \pm 10(5.7 \pm 2.2)$ & $18 \pm 5 \quad(3.9 \pm 1.1)^{a}$ & $19.5 \pm 1.9(330+50)^{a}$ & $11.4 \pm 2.3(310 \pm 60)^{a}$ & $6.740 \pm 2,110$ & $4,586 \pm 455^{a}$ \\
\hline Nonsurvivors & $41 \pm 15(9.0 \pm 3.3)$ & $28 \pm 7 \quad(6.2 \pm 1.5)^{a, b}$ & $37.0 \pm 6.9(1020 \pm 220)^{a, c}$ & $17.3 \pm 2.9(480 \pm 80)^{a, c}$ & $14,470 \pm 3,980^{\circ}$ & $5,166 \pm 567^{a}$ \\
\hline
\end{tabular}


Fig. 2. Mean responses of plasma ACTH and serum cortisol to stimulation with hCRH in 7 normal controls (CON., CO.) and 22 ICU patients (PAT., PA.). The insets show the total (TOT) and net integrated (NET) hormone responses, expressed as the secretory AUC. To con. vert ACTH concentrations to picomoles per L, multiply by 0.2202 ; to convert cortisol concentrations to nanomoles per L, multiply by 27.6 .
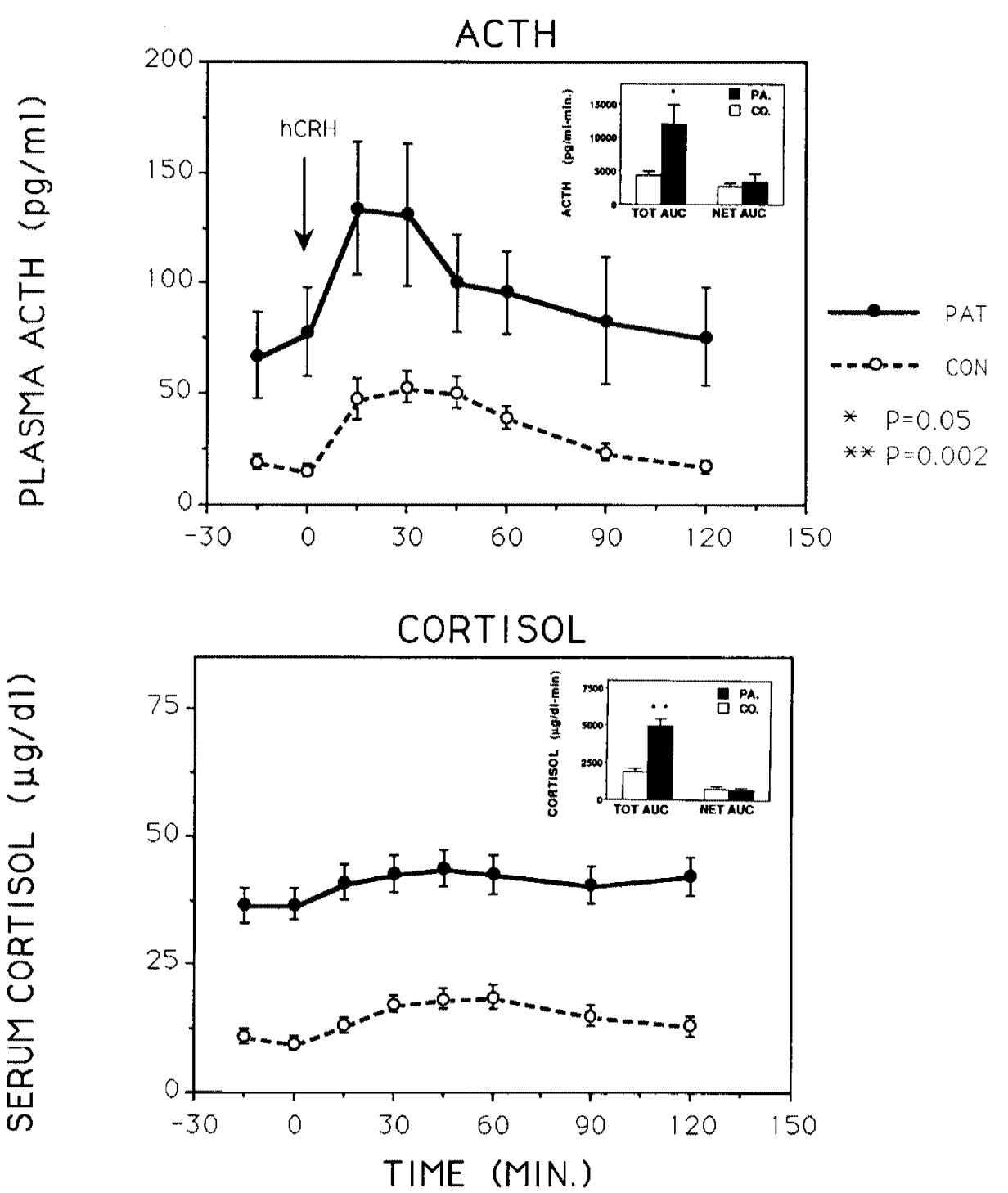

levels. This observation may be explained in several ways.

The responsiveness of the pituitary corticotroph to exogenous $\mathrm{CRH}$ in the presence of high endogenous glucocorticoid levels may be due to diminished sensitivity of the corticotroph to glucocorticoids in critically ill patients. Pituitary resistance to glucocorticoids in ICU patients could be caused by abnormalities in the transduction of the effects of glucocorticoids. Recently, a subgroup of acquired immunodeficiency syndrome patients was identified who had cortisol resistance characterized by elevated ACTH and cortisol concentrations and a diminished glucocorticoid receptor affinity in circulating mononuclear cells (30). Similar alterations in glucocorticoid receptor function may be partially responsible for changes in the HPA axis of ICU patients and could result in an augmented ACTH response to CRH.

Alternatively, the ACTH hypersecretion in ICU patients may also be explained by elevated levels of peptides and hormones with $\mathrm{CRH}$-releasing properties, which exaggerate the effects of endogenous and exogenous CRH on pituitary $\mathrm{ACTH}$ release. Vasopressin is a stress hormone frequently elevated during major surgery and severe illness (31). It exhibits a synergistic effect on ACTH release when given in combination with CRH (32-34). Its action makes it a likely candidate for the observed activation of the HPA axis during critical illness. Other peptides involved in CRH and ACTH release which may be elevated during major stress include angiotensin-II (35) and neuropeptide- $Y$ (36).

Another explanation for activation of the HPA axis during critical illness is the interaction between the immune and neuroendocrine systems. The inflammatory cytokines interleukin-1 $\beta$, interleukin- 6 , and tumor necrosis factor- $\alpha$ are frequently elevated in ICU patients $(37,38)$ and have prognostic significance. Endotoxin administration to normal volunteers is associated with a probably cytokine-mediated ACTH and cortisol release (39). In addition, interleukin-1 $\beta$, interleukin-6, and tumor necrosis factor- $\alpha$ have CRH- and/ or ACTH-releasing properties in vivo and in vitro (40-45). These potent peptides may, therefore, stimulate $\mathrm{ACTH}$ and cortisol secretion in critical illness.

Critical illness is often associated with conditions such as 

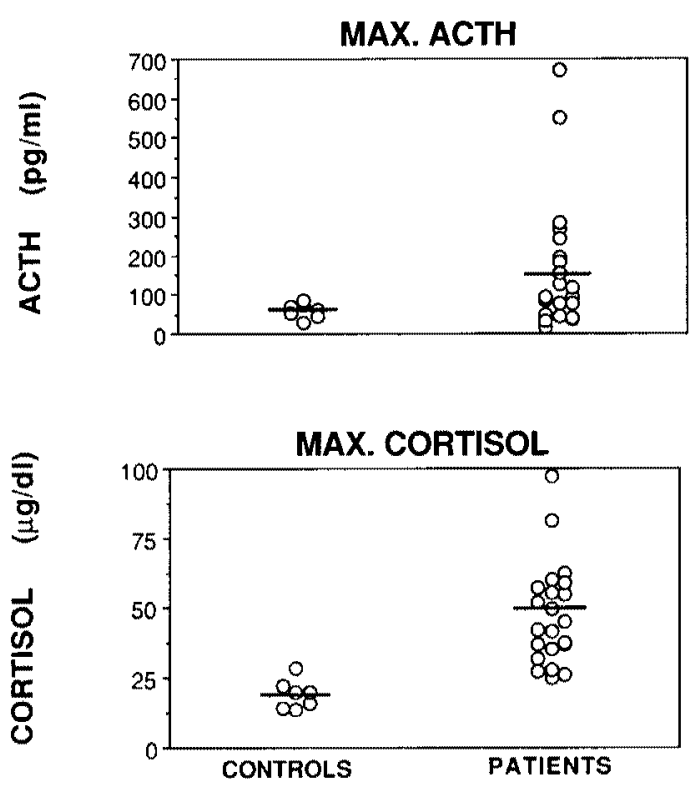

FIG. 3. Maximum plasma ACTH and serum cortisol concentrations after stimulation with hCRH in 7 normal controls and 22 ICU patients. The mean ACTH $(P=0.05)$ and cortisol concentrations $(P=0.0002)$ were significantly different in the 2 groups. To convert ACTH concentrations to picomoles per $\mathrm{L}$, multiply by 0.2202 ; to convert cortisol concentrations to nanomoles per L, multiply by 27.6 .

liver failure and acute renal insufficiency, which may affect the half-lives of plasma ACTH and cortisol in ICU patients. Although there are no data available concerning cleavage and metabolic clearance of ACTH and cortisol, respectively, in these patients, these conditions alone could theoretically result in elevated plasma $\mathrm{ACTH}$ and cortisol concentrations due to altered metabolism of these hormones. However, the plasma ACTH and cortisol responses to stimulation with hCRH in ICU patients and normal controls were parallel, arguing against a significantly prolonged half-life of these hormones.

In conclusion, ICU patients have a markedly altered responsiveness of their pituitary corticotroph to suppression with dexamethasone and stimulation with hCRH during critical illness. These findings are most likely due to hypersecretion of peptides with $\mathrm{CRH}$-like activity during life-threatening illness. However, pituitary resistance to glucocorticoids as a result of alterations in the signal transduction pathway of glucocorticoids cannot be excluded.

\section{Acknowledgments}

The human $\mathrm{CRH}$ used in this study was kindly provided by Bissendorf GMBH (Hannover, Germany). We wish to thank Ms. Doris Vollmer and Mrs. Heidi Hofmann for excellent technical assistance, and George P. Chrousos for his advice and editorial assistance.

\section{References}

1. Parker LN, Levin ER, Lifrak ET. 1985 Evidence for adrenocortical adaptation to severe illness. J Clin Endocrinol Metab. 60:947-952.

2. Drucker D, Shandling M. 1985 Variable adrenocortical function in acute medical illness. Crit Care Med. 13:477-497.

3. Drucker D, McLaughlin J. 1986 Adrenocortical dysfunction in acute medical illness. Crit Care Med. 14:789-791.

4. Udelsman R, Ramp J, Gallucci $W$, et al. 1986 Adaptation during surgical stress: a reevaluation of the role of glucocorticoids. J Clin Invest. 77:1377-1381.

5. Jurney TH, Cockrell JL, Lindberg JS, Lamiell JM, Wade CE. 1987 Spectrum of serum cortisol response to $A C T H$ in ICU patients: correlation with degree of illness and mortality. Chest. 92:292-295.

6. Udelsman R, Norton JA, Jelenich SE, et al. 1987 Response of the hypothalamic-pituitary-adrenal and renin-angiotensin axes and the sympathetic system during controlled surgical and anesthetic stress. J Clin Endocrinol Metab. 64:986 -994.

7. Wade CE, Lindberg JS, Cockrell JL, et al. 1988 Upon-admission adrenal steroidogenesis is adapted to the degree of illness in intensive care unit patients. J Clin Endocrinol Metab. 67:223-227.

8. Schein RMH, Sprung CL, Marcial E, Napolitano L, Chernow B. 1990 Plasma cortisol levels in patients with septic shock. Crit Care Med. 18:259-263.

9. Woolf PD, Cox C, Nichols D, McDonald JV, Hamill RW. 1990 The adrenocortical response to brain injury: correlation with the severity of neurological dysfunction effects of intoxication and patient outcome. Alcohol Clin Exp Res. 14:917-921.

10. Harris MJ, Baker RT, McRoberts W. 1990 The adrenal response to trauma, operation, and cosyntropin stimulation, Surg Gynecol Obstet. 170:513-516.

11. Carter JN, Eastmann CJ, Corcoran JM, Lazarus L. 1974 Effect of severe chronic illness on thyroid function. Lancet. 2:971-974.

12. Wehmann RE, Gregermannn RI, Burns WH, Saral L, Santos GW. 1985 Suppression of thyrotropine in the low-thyroxine state. $\mathrm{N}$ Engl J Med. 312:546-550.

13. Faber J, Kirkegaard C, Rasmussen B, Westh $H$, Busch-Soerensen M, Jensen W. 1987 Pituitary-thyroid axis in critical illness. J Clin Endocrinol Metab. 65:315-320.

14. Woolf PD, Hamill RW, McDonald JV, Lee LA, Kelly M. 1985 Transient hypogonadotropic hypogonadism caused by critical illness. J Clin Endocrinol Metab. 60:444-450.

15. Vogel AV, Peake GT, Rada RT. 1985 Pituitary-testicular dysfunction in burned men. J Clin Endocrinol Metab. 60:658-665.

16. Quint AR, Kasier FE. 1985 Gonadotropin determinations and thyrotropin-releasing hormone and luteinizing hormone-releasing hormone testing in critically ill postmenopausal women with hypothyroxinemia. J Clin Endocrinol Metab, 60:464-471.

17. Lephart ED, Baxter CR, Parker CR. 1987 Effect of burn trauma on adrenal and testicular steroid hormone production. J Clin Endocrinol Metab. 64:842-848.

18. Gebhart SSP, Watts NB, Clark RV, Umpierrez G, Sgoutas D. 1989 Reversible impairment of gonadotropin secretion in critical illness. Arch Intern Med. 149:1673-1641.

19. Zipser RD, Davenport MW, Martin $K_{L}$, et al. 1981 Hyperreninemic hypoaldosteronism in the critically ill: a new entity. J Clin Endocrinol Metab. 53:867-873.

20. Stern N, Beck FWJ, Sowers JR, Tuck M, Hsueh WA, Zipser RD. 1983 Plasma corticosteroids in hyperreninemic hypaaldosteronism: evidence for diffuse impairment of the zona granulosa. I Clin Endocrinol Metab. 57:217-220.

21. Findling JW, Waters VO, Raff H. 1987 The dissociation of renin and aldosterone during critical illness. J Clin Endocrinol Metab. 64:592-595.

22. Raff H, Findling JW. 1990 Aldosterone control in critically ill patients: ACTH, metoclopamide, and atrial natriuretic peptide. Crit Care Med. 18:915-920.

23. Mannelli M, Gheri RG, Selli C, et al. 1981 A study on human adrenal secretion. Measurement of epinephrine, norepinephrine, dopamine, and cortisol in peripheral and adrenal venous blood under surgical stress. J Clin Invest. 5:91-96.

24. Munck A, Guyre PM, Holbrook NJ. 1984 Physiological functions of glucocorticoids in stress and their relation to pharmacological actions. Endocr Rev. 5:25-44.

25. Keene AR, Cullen DJ. 1983 Therapeutic intervention scoring system: update 1983. Crit Care Med. 11:1-3.

26. Allolio B, Winkelmann W, Hipp FX. 1981 Effect of meclastine an $\mathrm{H} 1$-antihistamine on plasma $\mathrm{ACTH}$ in adrenal insufficiency. Acta Endocrinol (Copenh). 97:98-102. 
27. Gold PW, Loriaux DL, Roy A, et al. 1986 Responses to CRH in the hypercortisolism of depression and Cushing's disease. N Engl J Med. 314:1329-1335.

28. Schulte HM, Weissner D, Allolio B. 1990 The CRH test in late pregnancy: lack of ACTH and cortisol response. Clin Endocrinol (Oxf). 33:99-106.

29. Allolio B, Winkelmann W, Reincke M, et al. 1989 The pituitary adrenal axis in renal insufficiency: evidence for glucocorticoid resistance. Acta Endocrinol (Copenh). 120(Suppl 1):211.

30. Norbiato G, Bevilacqua $M$, Vago T, et al. 1992 Cortisol resistance in acquired immunodeficiency syndrome. J Clin Endocrinol Metab. 74:608-613.

31. Calogero AE, Norton JA, Sheppard BC, et al. 1992 Pulsatile activation of the hypothalamic-pituitary-adrenal axis during major surgery. Metabolism. 41:839-845.

32. Gillies GE, Linteon EA, Loery PJ. 1982 Corticotropin releasing activity of new CRF is potentiated several times by vasopressin. Nature. 299:355-357.

33. DeBold CR, Sheldon WR, DeCherny GS, et al. 1984 Arginine vasopressin potentiates $A C T H$ release induced by ovine CRF. J Clin Invest. 73:533-538.

34. Spinedi E, Negro-Vilar A. 1983 Angiotensin II and ACTH release: site of action and potency relative to $C R F$ and vasopressin. Neuroendocrinology. 37:446-453.

35. Gaillard RC, Riondel AM, Ling N, Muller AF. 1988 Corticotropin releasing factor activity of CRF 1-41 in normal man is potentiated by angiotensin II and vasopressin but not by desmopressin. Life Sci. 43:1935-1944.

36. Kamilaris TC, Calogero AE, Johnson EO, et al. Effect of neuropeptide $Y$ on hypothalamic-pituitary-adrenal function in the rat
[Abstract 58.9]. Proc of the 19th Annual Meet of the Soc for Neurosci. 1989.

37. Marano MA, Fong Y, Moldawer LL, et al. 1990 Serum cachectin/ tumor necrosis factor in critically ill patients with burns correlates with infection and mortality. Surg Gynecol Obstet. 170:32-38.

38. Calandra T, Gerain J, Heumann D, et al. 1991 High circulating levels of interleukin- 6 in patients with septic shock: evolution during sepsis, prognostic value, and interplay with other cytokines. Am J Med. 91:23-29.

39. Michie HR, Manogue KR, Spriggs DR, et al. 1988 Detection of circulating tumor necrosis factor after endotoxin administration. $\mathrm{N}$ Engl J Med. 318:1481-1486.

40. Sapolsky R, Rivier C, Yamamoto G, Plotsky P, Vale W. 1987 Interleukin-1 stimulates the secretion of hypothalamic corticotropin releasing factor. Science. 238:522-524.

41. Berkenbosch F, Van Oers J, Del Rey A, Tilders F, Besedovsky H. 1987 Corticotropin-releasing factor-producing neurons in the rat activated by interleukin-1. Science. 238:524-526.

42. Naitoh Y, Fukata J, Tominaga T, et al. 1988 Interleukin-6 stimulates the secretion of $\mathrm{ACTH}$ in conscious freely moving rats. Biochem Biophys Res Commun. 155:1459-1463.

43. Di Padova F, Pozzi C, Tondre MJ, Tritapepe R. 1991 Selective and early increase of IL-1 inhibitors IL-6, cortisol after elective surgery. Clin Exp Immunol. 85:137-142

44. Bernadini R, Kamilaris TC, Calogero AE, et al. 1990 Interaction between tumor necrosis factor-alpha, hypothalamic CRH, and adrenocorticotropin secretion in the rat. Endocrinology. 126:28762881.

45. Plata-Salaman CR. 1991 Immunoregulators of the nervous system. Neurosci Biobehavioral Rev. 15:185-215. 